\title{
Reply to Critics
}

\section{David Bolotin}

I am grateful to all of these respondents for their comments on my talk, and I have learned from each of them. I am also in general agreement with each of them. But rather than taking up space in spelling out our points of agreement, I will focus in this response on matters where we don't or at least might not agree.

Steven Eide is rightly concerned about the loss of respect for liberal education that has taken place in recent decades, a loss of respect that he traces in part to egalitarian dogma. Thus he concludes his response to me as follows:

But the liberal arts have been unable to establish a basis of respect amidst this ongoing crisis of rationalism. A philosophy student can challenge egalitarianism but only in a naysaying way if he can't offer a more rationally compelling alternative. Is the only option left for the liberal arts to recruit bullies of its own?

Now Aristotle's claim in the Nicomachean Ethics that justice is a proportion, in which honors and other such goods are distributed equally to those who are equal and unequally to those who are unequal, seems to me to be a step, at least, toward such a rationally compelling alternative. And even taken on its own, it raises a challenge to today's views that should in reason call for liberal inquiry. But, as it appears to me, no alternative to contemporary egalitarianism is likely to seem compelling to society at large, except in a few limited spheres, and there is little prospect that traditional liberal education will recover its lost respect anytime soon.

Still, this does not mean, as I hope and suppose that Mr. Eide agrees, that our only option is to recruit bullies of our own. For apart from the fact that any such bullies would be many fewer and far weaker than those on the opposite side, the attempt to recruit them would turn us into mirror-images of our critics, unable to learn or to teach anything worth knowing. 
Our best option, rather, as it seems to me, even if our situation were to become significantly worse than it is now, is to continue our efforts to learn and to teach, whether in accredited institutions of learning or elsewhere. And we would do well to keep in mind that without the labors of an extremely small number of scribes and scholars, the heritage of classical antiquity would almost surely not have survived the centuries of darkness that preceded the late medieval and early modern revival of learning.

Helen Andrews is rightly skeptical of the pundits who try to make sense of our hysterical woke activism by calling it a new religion. She regards it instead as a false substitute for religion, a substitute because, like religion, it demands sacrifices from its adherents-though I for one don't think these sacrifices amount to much, at least not yet-and false because unlike genuine religion, which can point to saints, who really exist, it and other such political movements can only point to utopias, which don't. Now she regards liberal education as akin to genuine religion in the sense that its positive effects are real and visible, in the form of wisdom that exists in some liberally educated persons. And she offers the tentative suggestion that “today's student radicals are so zealous in their attacks on liberal education because they detect in it an answer to the very longings that their radicalism promises to satisfy but never will."

I wonder, however, about this last suggestion, since I don't see why these activists wouldn't pursue liberal education themselves if they really detected in it an answer to their longings. It seems more plausible to me that they are blind to the rewards of liberal education, which would hardly be surprising, given the kind of teaching that they have known. But I would add that liberal education may not in fact be an answer to the longings that fuel their radicalism, at least not in the sense that it could satisfy them. Given that these longings, by her own account, point to utopias, which don't exist, there may well be nothing that could satisfy them. Liberal education might instead be an "answer" to them in the sense that it helps us to understand why they cannot be satisfied, while itself opening the way toward a life that is nevertheless worth living for a human being.

David Acevedo thinks that I greatly underestimate the severity of the problem for liberal education. He disagrees in particular with my claim that the ruling opinions of our political society are still "a belief in equality and a belief in freedom." In his view, "the concept of 'equality' has been replaced by its nefarious cousin 'equity,” which demands unequal treatment and even unequal 
outcomes favoring allegedly oppressed groups, and "freedom is virtually absent from American education." It seems to me, however, that what is called "equity" refers precisely to the equality that I spoke of in my talk, namely, "equality of results, in the sense of parity for all groups." Even the demand that we "handicap the 'privileged' in favor of the 'oppressed' in student admissions, faculty hiring, and classroom instruction" aims at bringing about such parity, the failure to attain which up to now is attributed to our history of oppression. And the word "equity" is preferred to "equality" because it seems more unequivocally just, thus helping to put a veil over the morally dubious character of the demand for equality in this sense.

As for freedom, it seems to me that it is still very highly prized. We are still deeply attached to the freedoms guaranteed by the First Amendment, so long as they don't threaten equality or parity for all groups, or rather for those groups that are thought to need extra support; and we are also much attached to other, more private freedoms, to sexual freedom in particular, especially for young women and girls, not to mention the freedom to define one's own gender. Or more generally, as it seems to me, the corruption that we see around us is primarily a corruption of our own principles, not some alien import.

But while I disagree with Mr. Acevedo about the ruling opinions of our society, I do agree with his suggestion that the best thing each of us can do now is "to return to the rigorous, disinterested study of what it means to be human, within or without the academy," by truly reading the Iliad, for instance. My only question in this regard is why he goes on to conclude that "this may be just what America needs to survive." I don't understand this. America is facing many serious challenges in addition to the crisis in liberal education, and I can't begin to conceive how a few people taking up his recommendation-for at best there would be only a few-could be the determining factor in saving the country. It might well contribute to making the country more deserving of survival. But the hope that it could save it seems to me to be so implausible that the effort of maintaining that hope would likely distort our study itself.

Better, it seems to me, to do the humble work of learning and teaching, while acknowledging that the fate of the country depends not so much on liberal education as on the political choices, involving schools and many other things as well, that we, together with our fellow citizens, have made in the past and will be obliged to make in the future. 
Alex Priou well understands that my talk was intended "not to reform the political community so much as to provoke individual reflection." And I did indeed contrast "the necessary closedness of the political community" with the "possible openness of the individual." But his characterization of the power of the individual, as a power, namely, "to reflect rationally and meaningfully on his own good," seems to me to be excessively narrow. We also care deeply about the good of the community, however limited that good might prove to be, and without the thoughtfulness and seriousness engendered by this larger care, we could never even hope to become genuine individuals. And from this perspective the crisis of contemporary political life, including the threat that it poses for liberal education, is not simply an evil, since it compels young people who might otherwise have paid little or no attention to politics to give it the serious thought that it deserves. 